\title{
A REVIEW ON THERMOGRAPHY IN DENTISTRY
}

\author{
Lakshmi P. S1, Shashi Kiran $M^{2}$, Tatu Joy $E^{3}$
}

1Postgraduate Student, Department of Oral Medicine and Radiology, Sree Mookambika Institute of Dental Sciences. ${ }^{2}$ Associate Professor, Department of Oral Medicine and Radiology, Sree Mookambika Institute of Dental Sciences. 3 Professor and HOD, Department of Oral Medicine and Radiology, Sree Mookambika Institute of Dental Sciences.

\section{ABSTRACT}

The study and application of biothermal process to assess health or disease is termed as Thermology and the imaging and visual evaluation of these thermal changes is termed "Thermography." Over the years, a variety of devices have been employed to measure body temperature. More recently with the advancement of technology, thermography as a tool has progressed into a beneficiary device in diagnosis. Thermography is a non-contact, non-destructive and non-invasive investigative method that utilises the heat from an object to detect, display and record thermal patterns and temperatures across the surface of the object. Variation in temperature distribution is attributed to variation in blood supply in various pathologies. Thermography is used to detect malignancies of the maxillofacial region, vitality of teeth, craniofacial neuralgia, TMJ disorders and chronic orofacial pain to list a few. This article highlights the basic principles of thermography and its beneficial role in maxillofacial medicine.

\section{KEYWORDS}

Dentistry, Infrared Rays, Orofacial Pain, Temporomandibular Disorders, Thermography,

HOW TO CITE THIS ARTICLE: Lakshmi PS, Kiran SM, Joy TE. A review on thermography in dentistry. J. Evolution Med. Dent. Sci. 2018;7(10):1289-1293, DOI: 10.14260/jemds/2018/294

\section{BACKGROUND}

Being a homeotherm humans are capable of maintaining a constant temperature of the body, which may be different from surrounding temperature. ${ }^{1}$ The body of homeotherms can be divided into the inner core and the outer periphery. The core temperature is preserved within a narrow limit (Approximately $42-33^{\circ} \mathrm{C}$ ). ${ }^{2}$ Regulation of inner core temperature is essential for normal performance of human body. Change in the core temperature by a few degrees is considered as a clear indication of probable illness. ${ }^{1}$

As the quantity of blood circulation at various parts of the skin differs, the temperature changes accordingly. Therefore, diseases affect the flow of blood and also result in irregularities in distribution of temperature and when assessed they will yield genuine diagnostic data. ${ }^{3}$ From the ancient past, bodily heat was considered as a major symbol of health and implementation of temperature determination along with thermal imaging. As time advanced an array of devices have been employed such as thermometers, thermistors, thermocouples and liquid crystal imaging systems for determining the body temperature. ${ }^{4}$ In this review we aim to discuss history, types of thermography and general requirements and guidelines and also highlighted the probable uses of thermography in dentistry.

\section{'Financial or Other Competing Interest': None.}

Submission 20-01-2018, Peer Review 14-02-2018,

Acceptance 21-02-2018, Published 05-03-2018.

Corresponding Author:

Dr. Lakshmi P. S,

Postgraduate Student,

Department of Oral Medicine and Radiology,

Sree Mookambika Institute of Dental Sciences,

Kulasekharam,

K. K. District.

E-mail: lakshmips251985@gmail.com

DOI: $10.14260 /$ jemds $/ 2018 / 294$

\section{(c) $(1)$}

\section{History}

Around 600 - 400 BC, pre-Hippocratic medicine of Greeks considered the measurement of temperature of human body as an essential feature. During $400 \mathrm{BC}$, body temperature was considered as a diagnostic symbol. ${ }^{5}$ Hippocrates measured the skin temperature of his ill patients by using his right hand and is described to be the first physician looking at body heat by putting mud on the abdomen and regarding its change in colour when getting dry. ${ }^{6}$ Galen (130 - 210 AD) emphasised that body heat was created due to the biocombustion of food.7

The Thermoscope which was invented by Galileo in 1592 is semi-quantitative and displayed shifts in the temperature. Santorio, an Italian physician and contemporary of Galileo, first used a thermometer based on Galileo's thermoscope. The thermometer displayed the variations in body temperatures in case of well-being as well as illness. 8,9

In Germany, 1872, Wunderlich introduced thermal measurement into clinical routine. In 1928, Czerny documented the earliest infrared image of a human subject in Frankfurt.10 The application of infrared thermography in the field of medicine began in Germany, 1952. Schwamm and Reeh developed a single detector infrared bolometer for diagnostics and the first medical association of thermography was founded by them in 1954, which is still operating as German Society for Thermography and Regulation Medicine and their method was patented in several countries including the USA. ${ }^{11}$

In the earlier days, single infrared detectors were used. As a result of advancement, contact thermography by electronic thermometers and liquid crystal plates were incorporated in diagnostic methods. Earlier camera, which was used for infrared imaging which was obtained from military systems along with being expensive had limitations due to poor resolution. Lack of computer hardware and software added to the disadvantages. Superior technology acceptable for medical causes was accessible since around 1980, which was then used globally, mostly LN2 cooled MCT (HgCdTe) scanners. Uncooled microbolometer Focal Plane Arrays (FPA) systems emerged economical after 2000. They were 
frequently used in medicine, despite some methodological problems leading to misinterpretation. ${ }^{11}$

\section{Types}

Depending upon the Type of Operation, Thermography can be categorised as follows-

1. Contact Method: Liquid crystal thermography (LCT).

2. Non-contact method: Infrared Telethermography (ITT) and Dynamic Area Telethermometry (DAT). ${ }^{5,12}$

Depending upon Determination of Temperature of the Skin-

1. Static Thermography: Temperature measure in a single instance of time.

2. Dynamic Thermography: Temperature measured in a series of many consecutive instances. 13

\section{Liquid Crystal Thermography}

A liquid crystal thermometer comprises of rubber layers, into which cholesteric crystals are organised in sheets that are seated on a frame. The rubber layers are arranged in such a way for inflation, so that the surface which is responsive to heat is well conformed to the contour of the body. The crystal sheets are arranged upon the areas to be inspected in order to determine the thermal changes. A shift is seen in the colour of the crystals is noticed. There is a change from a neutral colour to another colour as a reaction to the temperature of the surface. The colour presentation is then captured by polaroid photography. It provides an immediate hard copy of the resultant image. ${ }^{12}$ The limitation is that body surface temperature cannot be precisely determined by any equipment, which establishes contact with the skin. ${ }^{5}$

\section{Infrared Telethermography}

ITT also referred to as telethermometry, telethermography, digital infrared telethermographic imaging or electronic thermography is a non-contact method of determination of temperature, where the detector is placed at a single spot. ${ }^{12}$ It comprises of an amplifier-digitizer, an infrared detector, a microcomputer along with a video clip. ${ }^{14}$ The infrared detectors which are used are of various types and include linear array infrared detectors, single element infrared detector and two-dimensional array detectors. ${ }^{15}$ The single detector infrared radiation thermography functions in a manner such that as the infrared radiation emitted by the face entered the germanium lens, it passed via the mirrors placed perpendicular. The electric signals are converted to digital values by an amplifier. These signals are reconstructed into a digitised thermal image.

In normal subjects, ITT of the face have revealed that men have increased temperatures when compared to females. The logic behind this is that men have increased basal metabolic rate compared to women and the skin dissipates increased heat per unit area of body surface. It was found that men have greater temperatures than women over the 25 anatomic areas determined on the various parts of the face- for example orbit, cheek, chin, upper and lower lip. In a similar manner, ethnicity and age differences in facial temperature can also happen. ${ }^{16,17}$

\section{Dynamic Area Telethermometry}

DAT is a recent promising branch of infrared imaging which is directed at the quantitative measurement of the time dependence of skin temperature, assessing the modulation of temperature that has direct bearing on the thermoregulation of skin. Temporal behaviour of surface temperature is studied using a series of thermal images along with quantitatively assessing the temporal thermal behaviour of each subarea as a function of time. The temperature values pertaining to a subarea unit is obtained from each of a sequence of thermal images, comprises a time sequence of temperatures, the dynamics of which can be analysed quantitatively.12,14,15

\section{Indications}

Some of the Common Indications include

- Evaluation or follow-up of patients with or suspected temporomandibular dysfunction and other occlusive disorders, oral-facial pain and myofascial conditions of the head and neck.

- Evaluation or follow-up of inflammatory and infectious conditions related to the teeth, gingiva and mouth.

- Pre-procedure assessment for planning of interventional therapeutics.

- Follow-up to determine technical adequacy of medical or surgical interventions such as corrective dental measures, anaesthetic injection, vascularisation, environmental and liver detoxification, restoration of NEI imbalance and emotional restructuring.

- Follow-up to detect improvement, progression or spread of disease which may reflect change in condition.

- Confirmation of diagnostic inclusion criteria for clinical diagnostic purposes.

- Confirmation of diagnostic inclusion criteria for research purposes. ${ }^{18}$

\section{Contraindications and Limitations}

Contraindications Dental/ Systemic Health Thermal Imaging include-

- Presence of casts, bandages or other technical factors that preclude the ability to expose skin to a temperature equilibration environment.

- An uncooperative patient.18

General Clinical Requirements Guidelines by the Japanese Society of Thermology-

1. Keep the testing room free of wind. Turn off air conditioners.

2. Sources which emit infrared are to be kept away from the subject. Place a screen between any heater and the subject.

3. Keep controlled room temperature at over $25^{\circ} \mathrm{C}$. Record room temperature and humidity when taking each thermal image.

4. Stabilise the environment for at least 20 minutes before examination in the winter.

5. Subjects undergoing thermographic examination are to abstain from smoking at least 4 hours prior to the investigation and must be instructed as such.

6. Note the following items as subject-related information in the medical record including name, sex, age, chief 
complaint, history of tobacco use, history of alcohol consumption, handedness, painful position, abnormal position, region of cold sensitivity, past medical history, present clinical history, presence of medical treatment and detail of medical treatment, diagnostic entity, body temperature, time when the thermal image is taken, room temperature, room humidity and wall temperature.

7. Check the first thermal image again at the end of the sequence to confirm the reproducibility of images and changes over time. ${ }^{19}$

\section{Applications \\ Orofacial Pain}

According to a recent system of classification of the Delta T measurements of the facial area, Telethermographs were classified as 'normal' when Delta $\mathrm{T}$ values of selected anatomic area were ranging from 0.0 to $\pm 0.25^{\circ} \mathrm{C}$, 'hot' when area Delta $\mathrm{T}$ is $>-0.35^{\circ} \mathrm{C}$ and 'cold' when area Delta T was $<+$ $0.35^{\circ} \mathrm{C}$. When a Delta $\mathrm{T}$-value of a selected anatomic area is $\pm\left(0.26-0.35^{\circ} \mathrm{C}\right)$, the data is then categorised as 'equivocal.' Hot thermographs had the clinical diagnosis of-

1. Peripheral nerve mediated pain,

2. Sympathetically maintained pain,

3. Maxillary sinusitis,

4. Temporomandibular joint (TMJ) arthropathy.

Cold thermographs were seen having diagnosis of sympathetically independent pain and peripheral nervemediated pain. Subjects categorised with normal telethermographs were diagnosed with Trigeminal neuralgia, Cracked tooth syndrome, Psychogenic facial pain and pretrigeminal neuralgia. ${ }^{13,20}$

\section{Heat Transfer Behaviour across the Dentino-Enamel Junction in the Human Tooth}

Teeth generally have poor heat transfer properties and their overall thermal conductivity is about $0.6 \mathrm{Wm}^{-1} \mathrm{~K}^{-1} .21,22$ This creates methodological measurement challenges in addition to the numerous functional, biological and geometrical structure complexities. ${ }^{23,24}$ To address these technical challenges, a study was conducted using infrared thermography for the heat transfer behaviour. ${ }^{25}$ It is of importance to investigate the heat transfer and heat dissipation behaviour of the dentino-enamel junction (DEJ) of human tooth, since dentine and enamel have different thermophysical properties. The thermal diffusivities for dental hard tissues namely dentine and enamel were inferred from the time dependent temperature change at the respective layers. The thermal conductivities for these hard tissues were calculated to be $0.81 \mathrm{Wm}^{-1} \mathrm{~K}^{-1}$ and $0.48 \mathrm{Wm}^{-1} \mathrm{~K}^{-1}$ respectively. The temperature gradient distributes continuously across the enamel and dentine layers and their junction below a temperature of $42^{\circ} \mathrm{C}$, whilst a negative thermal resistance is observed at interfaces above $42^{\circ} \mathrm{C}$. These results suggest that the microstructure of the dentinenamel junction (DEJ) play an important role in tooth heat transfer and protects the pulp from heat damage.

\section{TMJ Disorders}

Examination of normal temporomandibular joint using thermography had shown symmetrical thermal patterns, which are with an average delta $\mathrm{T}$ values of $0.1^{\circ} \mathrm{C} .13,16$ Asymmetrical thermal patterns were seen in TMJ pain patients with temperatures increased over the involved region of TMJ. Mean area Delta T values were $+0.4^{\circ} \mathrm{C}, \pm 0.2^{\circ} \mathrm{C}$ Standard Deviation. ${ }^{26}$ In 1996, a double-blinded clinical study conducted by Beth and Gratt in order to compare the delta T values among patients undergoing orthodontic treatment, temporomandibular patients and asymptomatic controls of TMJ. The results revealed that the mean TMJ area delta $\mathrm{T}$ values were $+0.2^{\circ} \mathrm{C},+0.4^{\circ} \mathrm{C}$ and $+0.1^{\circ} \mathrm{C}$ in these groups. The results suggested that telethermography can differentiate patients undergoing active orthodontic treatment and patients with temporomandibular disorders (TMD). ${ }^{13,27}$

\section{In Assessing Pulp Vitality}

Infrared thermographic imaging for human teeth to assess the pulp vitality is under investigation. ${ }^{28,29}$ The basic concept was the tooth having a vital pulp tissue had a warmer tooth surface temperature when compared to the tooth without blood supply. ${ }^{30,31}$ It has been utilised to reveal that following cooling, non-vital teeth were slower to rewarm when compared to vital teeth. 32 The limitation of this procedure is that the teeth should be isolated with rubber dam, after which a span of acclimatisation is required before imaging. The procedure is complex requiring the subjects to rest for an hour before testing. ${ }^{28}$

\section{In Quantification of Thermal Insult to Pulp}

Pulps of tooth are exposed to various thermal insults during different treatment methods. In the recent times, Electrothermal Debonding (ETD) method is extensively utilised for debonding brackets in orthodontics. Even though this method has abundant benefits compared to conventional mechanical method, it can cause serious thermal pulpal damage. ${ }^{4}$ In 1999, Cummings and co-workers accomplished an in-vitro study on extracted premolars employing ETD. Examination of Thermal imaging revealed that the pulpal temperature raised from $16.8^{\circ} \mathrm{C}-45.6^{\circ} \mathrm{C}$, which can be a threat to pulpal vitality. It can be established from the study that ETD methods required periodic cooling of the teeth along with concurrent thermal imaging to avoid damage to the pulp. ${ }^{33}$

\section{CONCLUSION}

Thermography helps in the evaluation as well as staging of different dysfunctions of the head and neck region. The unique significance of thermography is both quantitative as well as qualitative appraisal, which aids in assessment of advancement of the disease in an orderly manner. ${ }^{3}$ Thermography is useful in dentistry due to the accurate measurements of regional temperature differences. Thermograms can provide significant connections about the methods of treatment and their efficacy. Thermograms can be secured in a database, a compact disc or printed on regular or special paper. ${ }^{34}$ With the innovation of novel equipments and the state of the art facility, thermography in the near future 
will certainly re-emerge as a unique research tool in maxillofacial medicine.

\section{REFERENCES}

[1] Jones BF. A reappraisal of the use of infrared thermal image analysis in medicine. IEEE Transactions in Medical Imaging 1998;17(6):1019-27.

[2] Bouzida N, Bendada A, Maldague XP. Visualization of body thermoregulation by infrared imaging. Journal of Thermal Biology 2009;34(3):120-6.

[3] Sudhakar S, Kayshap B, Reddy SP. Thermography in dentistry - revisited. Int J Biol Med Res 2011;2(1): 461-5.

[4] ChandraMouli PE, Kumar SM, Senthil B, et al. Application of thermography in dentistry - a review. Journal of Dental and Medical Sciences 2012;1(1):3943.

[5] Anbar M. Diagnostic thermal imaging: a historical technological perspective. In: Anbar M. edr. Quantitative dynamic telethermography in medical diagnosis. Boca Raton: CRC Press 1994: p. 1-9.

[6] Wunderlich CA. On the temperature in diseases: a manual of medical thermometry. New Sydenham Society 1871.

[7] Hall TS. Ideas of life and matter. Studies in the History of general physiology. Chicago: University of Chicago Press 1969.

[8] Wolf A. A history of science, technology, and philosophy in the 16th, 17th, and 18th Centuries. Thoemmes Press 1935.

[9] Bedford RE. Thermometry. In the new encyclopedia Britannica. 15 ${ }^{\text {th }}$ edn. Chicago: Encylopedia Brittanica 1992: p. 702-3.

[10] Czerny M. About photography in ultraroten. magazine for physics. 1929;53(1-2):1-2.

[11] Berz R, Sauer H. The medical use of infraredthermography history and recent applications. 2007.

[12] Anbar M, Gratt BM, Hong D. Thermology and facial telethermography. Part I: history and technical review. Dentomaxillofacial Radiology 1998;27(2):61-7.

[13] Gratt BM, Anbar M. Thermology and facial telethermography: Part II. Current and future clinical applications in dentistry. Dentomaxillofacial Radiology 1998;27(2):68-74.

[14] Anbar M. Fundamentals of computerized thermal imaging. In: Anbar M. edr. Quantitative dynamic telethermography in medical diagnosis. Boca Raton: CRC Press 1994: p. 99-131.

[15] Anbar M. Dynamic area telethermometry and its clinical applications. SPIE Proc 1995;2473:312-31.

[16] Gratt BM, Sickles EA. Electronic facial thermography: an analysis of asymptomatic adult subjects. Journal of Orofacial Pain 1995;9(3):255-65.

[17] Blaxter K. Energy exchange by radiation, convection, conduction and evaporation. Chap-7. Energy metabolism in animals and man. Cambridge: Cambridge University Press 1989: p. 86-99.
[18] Brioschi M, Usuki H, Crawford JBS, et al. Guidelines for dental-oral and systemic health infrared thermography. PAJMT 2015;2(1):44-53.

[19] Fujimasa I, Kanie R. The latest medical thermographytext for thermal imaging diagnosis. The Japanese Society of Thermology, Nagoya 1999: p. 144-56.

[20] Gratt BM, Graff-Radford SB, Shetty V, et al. A 6-year clinical assessment of electronic facial thermography. Dentomaxillofacial Radiology 1996;25(5):247-55.

[21] Linsuwanont $P$, Palamara JE, Messer HH. An investigation of thermal stimulation in intact teeth. Archives of Oral Biology 2007;52(3):218-27.

[22] Oskui IZ, Ashtiani MN, Hashemi A, et al. Thermal analysis of the intact mandibular premolar: a finite element analysis. International Endodontic Journal 2013;46(9):841-6.

[23] De Magalhaes FM, Ferreira NRA, Grossi PA, et al. Measurement of thermophysical properties of human dentin: effect of open porosity. Journal of Dentistry 2008;36(8):588-94.

[24] Marshall GW. Dentin: microstructure and characterization. Quintessence International 1993;24(9):606-17.

[25] Lin M, Liu QD, Kim T, et al. A new method for characterization of thermal properties of human enamel and dentine: Influence of microstructure. Infrared Physics \& Technology 2010;53(6):457-63.

[26] Gratt BM, Sickles EA, Wexler CE. Thermographic characterization of osteoarthrosis of the temporomandibular joint. Journal of Orofacial Pain 1993;7(4):345-53.

[27] McBeth SA, Gratt BM. A cross-sectional thermographic assessment of TMJ problems in orthodontic patients. Am J Orthod Dentofac Orthop 1996;109:481-8.

[28] Kells BE, Kennedy JG, Biagioni PA, et al. Computerized infrared thermographic imaging and pulpal blood flow: Part 1. A protocol for thermal imaging of human teeth. International Endodontic Journal 2000;33(5):442-7.

[29] Kells BE, Kennedy JG, Biagioni PA, et al. Computerized infrared thermographic imaging and pulpal blood flow: Part 2. Rewarming of healthy human teeth following a controlled cold stimulus. International Endodontic Journal 2000;33(5):448-62.

[30] Howell RM, Duell RC, Mullaney TP. The determination of pulp vitality by thermographic means using cholesteric liquid crystals: a preliminary study. Oral Surgery, Oral Medicine, Oral Pathology 1970;29(5):763-8.

[31] Gopikrishna V, Pradeep G, Venkateshbabu N. Assessment of pulp vitality: a review. International Journal of Paediatric Dentistry 2009;19(1):3-15.

[32] Pogrel MA, Yen CK, Taylor RC. Studies in tooth crown temperature gradients with the use of infrared thermography. Oral Surgery, Oral Medicine, Oral Pathology 1989;67(5):583-7. 
[33] Cummings M, Biagioni P, Lamey PJ, et al. Thermal image analysis of electrothermal debonding of ceramic brackets: an in vitro study. The European Journal of Orthodontics 1999;21(2):111-8.
[34] Sikdar SD, Khandelwal A, Ghom S, et al. Thermography: a new diagnostic tool in dentistry. Journal of Indian Academy of Oral Medicine and Radiology 2010;22(4):206-10. 